\title{
Intervensjonsstudien "Forebyggelse av lårhalsbrudd" Metode og praktisk gjennomføring
}

\author{
Elisabeth Kvaavik ${ }^{1,2}$, Haakon E. Meyer ${ }^{1,2}$, Guro Berge Smedshaug ${ }^{1,2}$, \\ Jan A. Falch ${ }^{3}$, Aage Tverdal ${ }^{1}$ og Jan I. Pedersen ${ }^{2}$ \\ ${ }^{I}$ Statens helseundersøkelser \\ ${ }^{2}$ Institutt for ernceringsforskning, Universitetet i Oslo \\ ${ }^{3}$ Hormonlaboratoriet og medisinsk avdeling, Aker sykehus \\ Korrespondanse: Haakon E. Meyer, Statens helseundersøkelser, Postboks 8155 Dep., 0033 Oslo \\ Telefon: 22242132 telefax: 22242101 e-post: haameyer@online.no
}

\begin{abstract}
SAMMENDRAG
Bakgrunn: Vitamin D-mangel er en potensielt viktig risikofaktor for osteoporotiske brudd. Vi har gjennomført en studie for å teste om vitamin $\mathrm{D}_{3}$ kan forebygge brudd blant sykehjemsbeboere. Her beskrives metoden og den praktiske gjennomføringen av studien.

Metode: En randomisert, dobbelt blindet, kontrollert studie på sykehjem. Intervensjonsgruppa fikk i 2 år $10 \square \mathrm{g}$ vitamin D daglig som $5 \mathrm{ml}$ tran og kontrollgruppa fikk $5 \mathrm{ml}$ tran der vitamin D var fjernet. Endepunktene var lårhalsbrudd og alle ikke-vertebrale brudd. Et enkelt studieopplegg ble vektlagt. På bakgrunn av styrkeberegningen var målsetningen å inkludere ca. 2000 deltakere.

Resultater: I alt 1144 beboere ved 51 sykehjem (av 106 forespurte) i Oslo, Lier og Bergen deltok. Deltakelsen ved de enkelte sykehjem varierte fra 3 til $57 \%$ av beboerne. Deltakerne var i gjennomsnitt 85 år og $3 / 4$ var kvinner. Kalsiuminntak fra ost og melk var i gjennomsnitt $450 \mathrm{mg} / \mathrm{dag}, 40 \%$ brukte vitamin Dtilskudd daglig mens $3 \%$ brukte kalsiumtilskudd. $1 / 3$ av deltakerne fullførte intervensjonen, ca. 1/3 avsluttet før 2 år pga. død og 1/3 avsluttet før 2 år av andre årsaker. De fleste avdelingslederne fant det lite arbeidskrevende å gjennomføre intervensjonen.

Konklusjon: Deltakelsen var lavere enn forventet idet det var betydelige vansker med å rekruttere sykehjemsbeboere til studien, men de avdelinger som deltok fant gjennomføringen av studien lite arbeidskrevende. Totalt ble 1144 inkludert i studien.
\end{abstract}

Kvaavik E, Meyer HE, Smedshaug GB, Falch JA, Tverdal A, Pedersen JI. The intervention study "Prevention of hip fractures". Nor J Epidemiol 2000; 10 (1): 79-85.

\section{ENGLISH SUMMARY}

Background: Vitamin D deficiency is a potential important risk factor for osteoporotic fractures. We have carried out a trial in nursing homes residents to study if supplementation with vitamin $\mathrm{D}_{3}$ can prevent such fractures. Here we present the method and the implementation of the study.

Method: A randomised, double-blinded, controlled trial in nursing homes. The intervention group received $10 \square \mathrm{g}$ vitamin D daily in $5 \mathrm{ml}$ cod liver oil for 2 years and the control group received $5 \mathrm{ml}$ cod liver oil without vitamin D. The endpoints were hip fractures and all non-vertebral fractures. It was considered important to use a trial that the nursing homes would find easy to implement. According to power calculation the aim was to include about 2000 participants.

Results: A total of 1144 residents from 51 nursing homes (of 106 invited) in Oslo, Lier and Bergen participated. The participation rate at the individual nursing home varied from 3 to $57 \%$. The participants were 85 years old and 3/4 were women. Mean calcium intake from cheese and milk was $450 \mathrm{mg} /$ day, more than $40 \%$ used a vitamin D supplement while only $3 \%$ used a calcium supplement. $1 / 3$ of the participants completed the 2 years intervention, about $1 / 3$ finished the intervention before 2 years because of death and $1 / 3$ finished before 2 years of other causes. The great majority of the wards did not find the intervention demanding.

Conclusion: The participation was lower than expected as recruiting nursing homes and nursing home residents posed considerable difficulty. However, the great majority of the ward staff at the participating wards did not find the intervention demanding. A total of 1144 was included in the study. 


\section{BAKGRUNN}

Lårhalsbrudd er et stort helseproblem blant eldre, og sykehjemsbeboere er spesielt utsatt for denne typen brudd $(1,2)$. Årlig får over 300 sykehjemsbeboere i Oslo lårhalsbrudd. Vitamin D-mangel er en potensielt viktig risikofaktor for osteoporotiske brudd (3). Vitamin D er viktig for kalsiumomsetningen i kroppen, og studier har vist at tilskudd av vitamin D kan redusere beintapet fra lårhalsen hos postmenopausale kvinner $(4,5)$. I tillegg er det holdepunkter for at vitamin Dmangel kan føre til muskelsvakhet, som igjen kan gi økt falltendens (6).

Dårlig vitamin D-status er utbredt blant eldre (7), og en case control-studie fra Oslo viste økt risiko for lårhalsbrudd blant personer med et lavt vitamin Dinntak (8). Den bruddforebyggende effekten av vitamin D er imidlertid uavklart. I en fransk randomisert studie utført blant institusjonaliserte eldre fant Chapuy og medarbeidere at et daglig tilskudd med $20 \square \mathrm{g}(800$ IE) vitamin $D_{3}$ pluss $1,2 \mathrm{~g}$ kalsium reduserte hyppigheten av lårhalsbrudd (9). Tilsvarende har en amerikansk randomisert studie blant hjemmeboende personer 65 år og eldre vist at et daglig tilskudd med 17,5 पg vitamin $\mathrm{D}_{3}$ pluss $0,5 \mathrm{~g}$ kalsium kan redusere hyppigheten av ikke-vertebrale brudd (10). En stor randomisert studie blant eldre i Amsterdam fant imidlertid ingen effekt på forekomsten av brudd ved intervensjon med bare vitamin D (10 पg/dag) (11). Imidlertid var den statistiske styrken til å påvise en effekt av vitamin $\mathrm{D}$ redusert pga. en langt lavere bruddhyppighet enn forventet $\mathrm{i}$ studiepopulasjonen. Det er således behov for nye studier for å avklare om vitamin D alene kan forebygge osteoporotiske brudd (12).

På denne bakgrunn har vi gjennomført en randomisert kontrollert studie hos beboerne på alders- og sykehjem for å teste om bruddhyppigheten blir lavere hos en gruppe som over en 2 års periode får et daglig tilskudd med $10 \square g$ vitamin $\mathrm{D}_{3}$ i form av vanlig tran sammenlignet med en kontrollgruppe som får vanlig tran hvor vitamin $\mathrm{D}_{3}$ er fjernet. Studien er utført på en minst mulig selektert gruppe alders- og sykehjemsbeboere, og det har vært viktig å ha et så enkelt studieopplegg som mulig for å gjøre den praktisk gjennomførbar på den enkelte institusjon.

Her presenteres en beskrivelse av metoden og gjennomføringen av studien. Hovedresultatene, dvs. effekten av vitamin D på bruddhyppigheten, er enda ikke analysert, og vil bli presentert i en annen artikkel. Det vil også bli gjort subgruppeanalyser hvor vi blant annet vil se på om effekten av vitamin D er forskjellig hos de med et høyt kalsiuminntak registrert ved studiestart versus de med et lavt kalsiuminntak, og mellom de som tok et vitamin D-tilskudd ved studiestart versus de som ikke gjorde det.

\section{METODE}

\section{Studiepopulasjonen}

Målet var å inkludere så mange som mulig av aldersog sykehjemsbeboerne i Oslo, Bergen og Lier i denne studien. Beboere som var permanent sengeliggende, som hadde en forventet gjenværende levetid på mindre enn $1 / 2$ år, som hadde betydelige vansker med å ta medisin, som var på korttidsopphold eller som alt tok tran ved studiens start var ikke aktuelle for studien (eksklusjonskriterier). Da vi ikke fant det riktig å kreve at beboere skulle seponere vitamin D-tilskudd for å kunne delta i studien, ble dette ikke gjort, men de som fikk mer enn $10 \square \mathrm{g}$ vitamin $\mathrm{D}$ daglig fra tilskudd var ikke aktuelle for studien. Bruken av vitamin Dtilskudd ble kartlagt ved studiestart.

\section{Gjennomforing av studien}

Det ble sendt invitasjonsbrev til sykehjemmene. Hvis sykehjemmets ledelse takket ja til invitasjonen, ble det som hovedregel avholdt et informasjonsmøte hvor representanter for ledelsen og de enkelte avdelinger deltok. Det var opp til de enkelte avdelingene å ta stilling til om de skulle delta i studien. Muntlig samtykke fra den enkelte beboer som var aktuell for studien ble innhentet før studiestart. I de tilfellene der beboerne ikke var mentalt adekvate ble pårørende informert.

Avdelingene rapporterte skriftlig tilbake til studieledelsen hvilke beboere som ble med i studien. Studiedeltakerne ble så plassert $\mathrm{i}$ gruppe $\mathrm{A}$ eller gruppe $\mathrm{B}$ på grunnlag av fødselsdag. Før studien startet ble månedens dager (1 til 31) tilfeldig fordelt $\mathrm{i}$ to grupper (gruppe A og B), og basert på dette ble deltakerne automatisk plassert i sin gruppe når de ble registrert $\mathrm{i}$ studiedatabasen. Personalet ved sykehjemmet hadde hverken innsikt i eller innflytelse på hvilke grupper beboerne kom til å bli plassert i.

\section{Sporreskjema}

For alle deltakerne i "Forebyggelse av lårhalsbrudd" (FLB) ble det fylt ut et kortfattet spørreskjema. Av hensyn til personalet som skulle fylle ut skjemaet var det viktig at det var enkelt og lite arbeidskrevende. Skjemaet inneholdt spørsmål om inntak av hele brødskiver per dag, ost som pålegg (for enkelthets skyld ble alle typer ost slått sammen til et spørsmål), melk som drikke, vitamin- og kalsiumtilskudd, bevegelighetsstatus (hvorvidt beboeren trengte støtte for å gå), fall siste tre måneder, tidligere lårhalsbrudd samt høyde og vekt.

\section{Intervensjon og oppfolging}

Gruppe A fikk tran merket A og gruppe B fikk tran merket B. Det ble også brukt fargekode ved at type A- 
tran hadde gul kork og etikett mens type B-tran hadde hvit kork og etikett. Den ene typen tran var vanlig tran, den andre typen en vanlig tran hvor vitamin D var fjernet. Vitamin D ble ekstrahert fra tranen vha. blekjordsteknikk, deodorisasjon og molekylær destillasjon. Vitamin A ble også fjernet i denne prosessen, og ble derfor tilsatt igjen $\mathrm{i}$ form av retinyl palmitat, som er den naturlige formen av vitamin A som finnes i tran. Nivåene av vitamin $\mathrm{D}$ og $\mathrm{A} \mathrm{i}$ den vanlige tranen ble kontrollert og eventuelt justert.

Både prosjektledelsen og sykehjemmene var blindet for hvilken av de to typene tran som inneholdt vitamin D. Deltakerne i studien fikk $5 \mathrm{ml}$ tran hver dag i 2 år, noe som tilsvarte $10 \square \mathrm{g}$ vitamin D daglig for intervensjonsgruppa.

Følgende hendelser var årsak til å avslutte trantagingen for en deltaker: beboeren ble satt på vitamin D-holdige preparat, beboeren ønsket ikke lenger å delta i studien, sammenhengende avbrudd i traninntaket på mer enn 1 måned eller dødsfall.

Ved studiestart fikk avdelingen utlevert en studieprotokoll med registreringsskjema for hver enkelt deltaker. Registreringsskjemaene hadde samme fargekode som tranen og hadde plass til opplysninger om når og hvorfor deltakeren eventuelt sluttet å ta tran samt rubrikk til registrering av beinbrudd. I tillegg inneholdt protokollen praktisk informasjon om studiens gjennomføring. Denne informasjonen kom i tillegg til muntlig informasjon ved studiestart. En av prosjektmedarbeiderne besøkte avdelingen ved avdelingsleder/ annen kontaktperson om lag hvert halve år i de 2 årene intervensjonen varte. Ved disse besøkene ble behandlingsstatus hos hver enkelt deltaker kartlagt og det ble registrert hvorvidt deltakerne hadde hatt beinbrudd siden forrige besøk. Ved hvert besøk ble registreringsskjemaene samlet inn og nye levert ut. Brudd ble bekreftet ved hjelp av epikrise eller røntgenbeskrivelse. For å validere registreringen av lårhalsbruddene ved sykehjemmene, ble det også innhentet opplysninger om lårhalsbrudd ved hjelp av utskrivningsregistrene ved sykehusene i Oslo, Drammen og Bergen. I hovedanalysen vil det primært bli utført en analyse etter behandlingsintensjonsprinsippet (intention to treat-analysis), dvs. at alle deltakerne vil bli fulgt i 2 år eller til død uavhengig av om de har sluttet å ta tran. Av denne grunn ble brudd i perioden etter at de sluttet å ta tran også registrert. Dødsdatoene til deltakerne ble bekreftet ved hjelp av Det sentrale personregisteret.

Intervensjonen startet med første sykehjem i oktober 1995 og siste sykehjem i juni 1998. Siste sykehjem avsluttet intervensjonen 30.06.99. Hvert enkelt sykehjem deltok i intervensjonen i 2 år eller til 30.06.99, dvs. i minst ett år.

Studien ble godkjent av Datatilsynet, Statens helsetilsyn og Regional komite for medisinsk forskningsetikk, som gav oss anledning til å inkludere beboere etter å ha innhentet muntlig samtykke fra disse. Dersom en beboer ikke var mentalt adekvat, fikk vi lov til å inklu- dere denne dersom pårørende ikke hadde noe imot det og dersom beboeren ikke gav uttrykk for at hun/han ikke ville ha tran.

På et underutvalg, som ikke vil bli omtalt nærmere her, ble det gjort beinmassemåling, gripestyrkemåling og blodprøvetaking ved studiens start og etter ett år for å se om intervensjonen hadde noen innvirkning på disse parametrene. De aktuelle blodprøvene var PTH, ionisert kalsium, 25-hydroxyvitamin D og osteocalcin i serum. Fra de beboerne som fikk gjort disse målingene krevdes det skriftlig samtykke.

\section{Statistisk styrke}

Ved studiestart var det ca. 4500 alders- og sykehjemsbeboere i Oslo. Dersom en bruker tall fra 1988-89 (13), ville en forvente 685 lårhalsbrudd hos disse over en 2 års periode (7,6\% per år), mens data fra deler av Oslo i 1992/93 tydet på at 6,2\% av sykehjemsbeboerne fikk lårhalsbrudd i løpet av ett år (8). Lårhalsbrudd utgjør ca. 50\% av alle ikke-vertebrale brudd i en slik populasjon (9). Ved å legge til grunn et konservativt estimat på at $6 \%$ av beboerne årlig vil brekke lårhalsen, vil vår studie ha $80 \%$ styrke til å kunne påvise en $30 \%$ reduksjon av lårhalsbrudd og $20 \%$ reduksjon av ikkevertebrale brudd på 5\% signifikans-nivået ved totalt å inkludere 2250 personer. Nye data fra Oslo i 1996/97 viser imidlertid at den alders-spesifikke insidensen av lårhalsbrudd har holdt seg uforandret siden 1988/89 (14). Det er derfor grunnlag for å anta at insidensen blant sykehjemsbeboere også har holdt seg på sammen nivå, dvs. 7,6 brudd blant 100 beboere per år. Bruker en denne insidensen vil 1798 personer gi studien den samme styrken som beregnet over.

\section{Sporsmål ved avslutning av intervensjonen}

Når intervensjonen ble avsluttet ved den enkelte avdeling, ble avdelingsleder/annen kontaktperson stilt følgende spørsmål: 1) Har det vært problemer i forbindelse med intervensjonen (av et hvilket som helst slag), 2) Har det vært problemer i forbindelse med å gi beboerne tran (søl, lukt og lignende), 3) Har beboerne fătt tran regelmessig? Disse spørsmålene ble stilt til 69 avdelinger ved 29 sykehjem i perioden 26.01.98 til 30.06.99. Det var 63 av de 69 avdelingene som besvarte spørsmålene.

\section{RESULTATER}

Ett hundre og seks alders- og sykehjem i Oslo, Lier og Bergen (ca. 6500 beboere) fikk tilbud om å delta $i$ FLB, og 51 (48\%) av dem deltok. Deltakelsen ved det enkelte sykehjem varierte fra $3 \%$ til $57 \%$ av beboerne (gjennomsnitt 22,4\%). Deltakelsen ved de enkelte avdelinger var stort sett høyere enn ved sykehjemmet som helhet da ikke alle avdelinger ved det enkelte sykehjem deltok i studien.

Av totalt 1144 deltakere i FLB var 3/4 kvinner. 
Gjennomsnittsalderen for deltakerne var om lag 85 år (tabell 1). Kalsiuminntaket fra ost som pålegg og melk som drikke var omtrent $450 \mathrm{mg}$ daglig. Mens over $40 \%$ av deltakerne brukte et vitamin D-tilskudd, var det nesten ingen som brukte kalsiumtilskudd. Mer utfyllende beskrivelse av deltakerne ved studiens start er vist $\mathrm{i}$ tabell 1.

Av de 1144 deltakerne i FLB var det 1/3 som ble behandlet i 2 år, ca. 1/3 som avsluttet behandlingen før 2 år pga. dødsfall og 1/3 som avsluttet behandlingen før 2 år av andre årsaker enn død (tabell 2). De viktigste årsakene til å slutte behandlingen før 2 år var at deltakeren ikke ønsket å ta tran lenger, manglende oppfølging fra personalets side og sykdom (tabell 2). De som sluttet behandlingen før 2 år tok i gjennomsnitt tran i 10 måneder. Av de som sluttet behandlingen av andre årsaker enn død, var det 160 som døde i perioden fra de sluttet med tran til 2 år etter start. Totalt ble deltakerne fulgt i ca. 1700 observasjonsår.

I kartleggingen av avdelingenes opplevelse av gjennomføringen av intervensjonen var det $16 \%$ (10) av avdelingslederne som oppga at de hadde hatt en eller annen form for problem med gjennomføringen. Ved å gå inn på mer konkrete sider ved det å gi beboerne tran, som søl og lukt og regelmessigheten av å gi beboere tran, var det få som hadde funnet dette problematisk (tabell 3).

\section{DISKUSJON}

Det var et mål å lage et enkelt studieopplegg for dermed å få med så mange som mulig av beboerne ved alders- og sykehjemmene i Oslo, Lier og Bergen. Om lag halvparten av de inviterte alders- og sykehjemmene takket ja til å delta, men det var stor variasjon i hvor mange avdelinger og hvor stor andel av beboerne ved hvert sykehjem som var med i studien. Avdelingene som deltok i studien fant det imidlertid lite arbeidskrevende å gjennomføre den 2-årige intervensjonen.

I forkant av intervensjonsstudien FLB ble det utført en forundersøkelse (1085 beboere ved 16 sykehjem i Oslo) for å se på mulighetene for å gjennomføre den planlagte intervensjonen (15). Det ble samtidig utført en kostholdsundersøkelse (101 beboere ved 3 sykehjem i Oslo) (15). I intervensjonsstudien fant man at $22 \%$ av deltagerne var avhengig av rullestol, mens dette tallet var 34\% i forundersøkelsen og 30\% i kostholdsundersøkelsen. Dette kan tyde på at de minst føre i mindre grad har deltatt i FLB. Gjennomsnittsalder, kjønnsfordeling og kroppsmasseindeks var den samme i FLB som i kostholdsundersøkelsen. Det er imidlertid viktig å merke seg at metodene i forundersøkelsen, kostholdsundersøkelsen og i FLB var ulike. I forundersøkelsen foregikk kartleggingen på avdelingsnivå ved telefonsamtale med avdelingsleder hvor det ble spurt etter blant annet andel som var avhengig av rullestol og andel som brukte vitamin D- og kalsiumtilskudd. Metoden som ble brukt i kostholdsundersøkelsen var intervju av beboeren i de tilfeller denne var så orientert at vedkommende kunne redegjøre for blant annet kostholdet. Hvis ikke beboeren kunne intervjues, ble en fra personalet intervjuet om beboerens kosthold. I FLB var det en representant fra personalet som fylte ut et tilsendt kostspørreskjema på vegne av beboeren, noen ganger i samarbeid med beboeren.

Tabell 1. Beskrivelse av 1144 deltakere i studien "Forebyggelse av lårhalsbrudd".

\begin{tabular}{|c|c|}
\hline \multicolumn{2}{|l|}{ Karakteristikk } \\
\hline Kvinner (\%) & 75,9 \\
\hline Alder (år) ${ }^{1}$ & $84,7 \pm 7,4$ \\
\hline $\operatorname{BMI}\left(\mathrm{kg} / \mathrm{m}^{2}\right)^{1}$ & $22,3 \pm 4,6$ \\
\hline Spiser færre enn 3 hele brødskiver per dag (\%) & 27,1 \\
\hline Brødskiver (hele) med ost (minst 2 pr. dag) $(\%)$ & 23,5 \\
\hline Melkeglass (minst 3 pr. dag) (\%) & 34,8 \\
\hline Kalsiuminntak fra melk og ost $(\mathrm{mg} / \mathrm{dag})^{1}$ & $451 \pm 196$ \\
\hline Bruker vitamin D-tilskudd (\%) & 41,4 \\
\hline Bruker kalsiumtilskudd (\%) & 2,9 \\
\hline Fall $(\%)^{2}$ & 33,1 \\
\hline \multicolumn{2}{|l|}{ Tidligere lårhalsbrudd (\%) } \\
\hline Nei & 67,1 \\
\hline $\mathrm{Ja}$ & 27,5 \\
\hline Vet ikke & 5,4 \\
\hline \multicolumn{2}{|l|}{ Avhengig av gangstøtte (\%) } \\
\hline Nei & 34,0 \\
\hline Ja, stokk eller krykker & 43,7 \\
\hline Rullestolbruker & 22,3 \\
\hline
\end{tabular}

${ }^{2}$ Minst ett fall i løpet av de siste 3 månedene.

Tabell 2. Behandlingsstatus blant 1144 deltakere i studien "Forebyggelse av lårhalsbrudd".

\begin{tabular}{lr}
\hline Behandlingsstatus & $\mathrm{n}(\%)$ \\
\hline Behandlet i 2 år & $383(33,5)$ \\
Sluttet behandlingen før 2 år pga. død & $332(29,0)^{1}$ \\
Sluttet behandlingen før 2 år av andre & \\
årsaker enn død & $403(35,2)$ \\
Årsak til sluttet behandling før 2 år: & \\
$\quad$ Manglende oppfølging fra avdelingen & 87 \\
Startet med vitamin D & 7 \\
Sykdom/terminal fase & 77 \\
Dårlig matlyst, gulping, kvalme & 40 \\
Ville ikke delta mer & 184 \\
Uoppgitt & 8 \\
Tapt for oppfølging (loss to follow-up) & $26(2,3)$ \\
\hline 1332 deltakere sluttet med behandlingen før 2 år pga. døds- \\
fall, og i tillegg døde 160 etter at de hadde sluttet å ta tran \\
og før det var gått 2 år (totalt 492).
\end{tabular}

Tabell 3. Avdelingenes opplevelse av gjennomføringen av intervensjonen.

\begin{tabular}{lcc}
\hline & $\begin{array}{c}\text { Har det vært problemer } \\
\text { med å gi beboerne tran } \\
\text { (søl, lukt og lignende)? }\end{array}$ & $\begin{array}{c}\text { Har beboerne fått } \\
\text { tran regelmessig? }\end{array}$ \\
\hline Nei \% (n) & $90 \%(57)$ & $0 \%(0)$ \\
Ja \% (n) & $8 \%(5)$ & $95 \%(60)$ \\
Vet ikke \% (n) & $2 \%(1)$ & $5 \%(3)$ \\
\hline
\end{tabular}


I en tidligere case control-studie hos hjemmeboende $\mathrm{i}$ Oslo ble det funnet at et inntak av mindre enn 3 brødskiver daglig var assosiert med økt risiko for lårhalsbrudd (8). I FLB var det omtrent $1 / 4$ av deltakerne som spiste mindre enn 3 brødskiver daglig. Dette er litt større andel enn i case control-studien der $1 / 5$ av kontrollene spiste mindre enn 3 brødskiver daglig. Det bemerkes at disse kontrollene var hjemmeboende og yngre enn deltakerne i FLB. Til sammenligning var det hele $43 \%$ i kostholdsundersøkelsen (15) som spiste mindre enn 3 brødskiver per dag. Denne forskjellen kan imidlertid delvis være forårsaket av metodiske forhold da det i aldersinstitusjoner kan være ulike oppfatninger om hva som er hele og halve skiver. Sammenlignet med kostholdsundersøkelsen (15) var det en like stor andel i FLB som drakk minst 3 glass melk daglig (omtrent 34\%).

I følge Statens råd for ernæring og fysisk aktivitet bidrar ost og melk med om lag 2/3 av kalsiuminntaket $i$ et norsk kosthold (1998) (16). Med dette som grunnlag vil deltagerne i FLB ha et estimert totalt kalsiuminntak på om lag 680 mg per dag i snitt. Det må imidlertid tas høyde for at matvarenes prosentvise bidrag til næringsstoffene blant en sykehjemsbefolkning kan skille seg ut fra normalbefolkningen. I en undersøkelse ved et sykehjem i Oslo ble det funnet at ost og melk bidrog med hele $88 \%$ av det totale kalsiumminntaket, men det må understrekes at det var få deltakere i undersøkelsen og at den veide registreringen som ble benyttet foregikk over kun 4 dager (17). I forhold til Statens råd for ernæring og fysisk aktivitets anbefaling om et daglig inntak på $800 \mathrm{mg}$ kalsium for begge kjønn over 75 år var kalsiuminntaket i FLB noe lavt (18). I kostholdsundersøkelsen (15) var medianinntak av kalsium fra ost, melk, yoghurt og kaffefløte $525 \mathrm{og}$ $695 \mathrm{mg}$ daglig for hhv. kvinner og menn (uten å justere for at disse matvarene bidrar med bare omtrent 2/3 av det totale kalsiuminntaket). Andre norske studier (19-23) har også til dels funnet et høyere kalsiuminntak blant eldre mennesker, men det er viktig å være klar over forskjellene i metoder som har vært brukt, ulikheter $\mathrm{i}$ alderssammensetningen og $\mathrm{i}$ bosituasjonen (institusjonaliserte versus hjemmeboende). En del utenlandske studier har funnet et kalsiuminntak blant eldre som har variert fra et lavere til et høyere inntak enn det som ble funnet i FLB $(4,5,9,10,24)$.

I følge forundersøkelsen til FLB (15) var det $68 \%$ av beboere ved sykehjem i Oslo som brukte et kosttilskudd som inneholdt vitamin D. Denne andelen var i følge kostholdsundersøkelsen omtrent $50 \%$, mens det $\mathrm{i}$ FLB var $41 \%$ som brukte et vitamin D-tilskudd daglig. I forundersøkelsen ble avdelingene oppringt og i en del tilfelle ble det opplyst at "alle" beboerne ved avdelingen fikk kosttilskudd, noe som kan være årsaken til den høye verdien i denne undersøkelsen.

Det var svært få av deltakerne som brukte kalsiumtilskudd både i FLB (3\%) og i forundersøkelsen og i kostholdsundersøkelsen ( $2 \%$ i begge). Inntaket på gjennomsnittlig $680 \mathrm{mg}$ kalsium daglig sammen med det lave antallet som tok kalsiumtilskudd står i stor kontrast til kalsiuminntaket til deltakerne i Chapuy og medarbeideres studie (9). De hadde et daglig kalsiuminntak på omtrent $500 \mathrm{mg}$ (i gjennomsnitt) fra kost pluss et tilskudd på 1,2 g daglig i intervensjonsgruppa. Til tross for at den franske studien (9) viste at dette kalsiuminntaket sammen med $20 \square \mathrm{g}$ vitamin D daglig gav redusert risiko for lårhalsbrudd er det altså en ubetydelig andel av sykehjemsbeboere som i dag får en slik kombinasjon. Ikke minst på denne bakgrunn er det viktig å finne ut om et tilskudd med bare vitamin D kan ha en bruddforebyggende effekt. Dette er ennå ikke avklart.

I FLB var det omtrent $1 / 3$ av deltakerne som hadde falt minst en gang de siste 3 månedene før studiestart. Dette tallet er omtrent dobbelt så høyt som i Chapuy og medarbeideres studie (9). I Meyer og medarbeideres studie (8) var det en kraftig økt risiko for lårhalsbrudd for dem som hadde minst 3 fall siste år.

Vi fikk med langt færre enn planlagt i studien. Rekalkulering av den statistiske styrken basert på at 7,6\% får lårhalsbrudd per år og det faktum at vi endte opp med 1144 beboere (1700 observasjonsår) gir studien en styrke på $80 \%$ til å påvise en reduksjon av lårhalsbrudd på $42 \%$ og en reduksjon av ikke-vertebrale brudd på ca. $30 \%$ med et signifikansnivå på $5 \%$.

Det at vi ikke fikk med så mange $\mathrm{i}$ studien som ønsket kan forklares ut fra at bare halvparten av de inviterte sykehjemmene takket ja til å delta i studien samt at ikke alle avdelingene ved disse sykehjemmene deltok. Deltakelsen ved det enkelte sykehjem varierte fra 3 til $57 \%$ av beboerne. Dette er i samsvar med og til dels bedre enn i en nederlandsk studie (11) der $60 \%$ av de inviterte sykehjemmene takket ja til å delta og deltakelsen varierte fra 5 til $30 \%$ av beboerne ved det enkelte sykehjem. Grunnene som ble gitt for ikke å delta i FLB var i hovedsak frykt for et økt arbeidspress på et allerede presset personale ved sykehjemmene. På en del sykehjem foregikk det omorganiseringer, på andre var det generelt en ustabil bemanningssituasjon, og noen sykehjem var alt engasjert $i$ andre studier.

På bakgrunn av en ustabil bemanningssituasjon ved sykehjemmene som deltok i FLB oppstod der i noen tilfelle problemer med kontinuiteten av intervensjonen. Det var særlig skifte av avdelingsleder som medførte problemer. Av de totalt 1144 deltakerne var det 87 som avsluttet behandlingen for 2 år pga. manglende oppfølging fra sykehjemspersonalets side. Ved noen sykehjem var det hele avdelinger som avsluttet behandlingen pga. skifte av avdelingsleder.

Den viktigste enkeltårsaken til å avslutte behandlingen før 2 år, var dødsfall. Av de 1144 studiedeltakerne var det 332 (29\%) som avsluttet før 2 år pga. død. Dette er flere enn i den franske og den nederlandske studien $(9,11)$. Av de som sluttet behandlingen før 2 år av andre årsaker enn død, utgjorde de som ikke ønsket å delta lenger den største gruppa (16\% av alle 
studiedeltakerne). Om lag 7\% av deltakerne avsluttet behandlingen pga. sykdom, til sammenligning var det $3 \%$ av deltakerne i Chapuy og medarbeideres studie (9) som avsluttet pga. sykdom. Årsaken til de lavere tallene i den franske studien kan delvis skyldes at studien varte i 18 måneder mot 24 måneder i FLB og at deltakerne $\mathrm{i}$ den franske studien var friskere. De franske studiedeltakerne måtte blant annet være oppegående (ikke sitte i rullestol) og ha forventet gjenværende levetid på 18 måneder.

Pga. vitamin D's evne til å lagres i kroppen vil vitaminet kunne ha en forebyggende effekt utover den perioden deltakerne faktisk ble behandlet. De som avsluttet behandlingen for 2 år av andre årsaker enn død, tok i gjennomsnitt tran i 10 måneder. Effekten av vitamin D-tilskuddet i denne perioden vil kunne ha effekt i flere måneder utover den perioden de tok tran $(7,25,26)$.

Vi kartla personalets opplevelse av å gjennomføre intervensjonen i 63 av de 120 avdelingene som deltok i
Oslo og Lier. Når først avdelingene hadde deltatt i studien i to år oppgav de fleste at det ikke hadde medført problemer å gjennomføre intervensjonen. Samtlige avdelingsledere oppga at beboerne som hadde deltatt $i$ studien hadde fått tran hver dag i løpet av den tiden de fikk behandling. Det kan synes som om engstelsen for merarbeid og problemer var overdrevne hos de avdelingene som valgte ikke å delta i studien. Når man planlegger studier i denne typen populasjoner bør man regne med lav deltakelse.

\section{ANERKJENNELSE}

Vi vil gjerne takke Thale Briseid og Anne-Marie Aas for medvirkning til forberedelsene til studien. Vi vil også takke Hilde og Roger Antonsen for medvirkning til datainnsamlingen og de ansatte og beboerne ved sykehjemmene i Oslo, Lier og Bergen som deltok i studien for innsatsen med gjennomføringen av intervensjonen. Studien ble støttet økonomisk av Peter Møller avd. av Orkla ASA, Tine Norske Meierier, Oslo kommune og Odd Fellow.

\section{REFERANSER}

1. Cumming RG. Nursing home residence and risk of hip fracture. Am J Epidemiol 1996; 143: 1191-1194.

2. Johnell O, Sernbo I. Health and social status in patients with hip fractures and controls. Age Ageing 1986; 15: 285-291.

3. Feldman D, Malloy PJ, Gross C. Vitamin D: Metabolism and action. In Marcus R, Feldman D, Kelsey J, editors. Osteoporosis. San Diego: Academic Press, 1996; 6: 205-235.

4. Dawson-Hughes B, Harris SS, Krall EA, Dallal GE, Falconer G, Green CL. Rates of bone loss in postmenopausal women randomly assigned to one of two dosages of vitamin D. Am J Clin Nutr 1995; 61: 1140-1145.

5. Ooms ME, Roos JC, Bezemer PD, van der Vijgh WJ, Bouter LM, Lips P. Prevention of bone loss by vitamin D supplementation in elderly women: a randomised double-blind trial. $J$ Clin Endocrinol Metab 1995; 80: 1052-1058.

6. Mets T. Calcium, vitamin D, and hip fractures. Incidence of falls may have decreased [letter]. BMJ 1994; 309: 193.

7. Mowé M, Bøhmer T, Haug E. Serum calcidiol and calcitriol concentrations in elderly people: variations with age, sex, season and disease. Am J Clin Nutr 1994; 59: 317-324.

8. Meyer HE, Henriksen C, Falch JA, Pedersen JI, Tverdal A. Risk factors for hip fracture in a high incidence area: A case-control study from Oslo, Norway. Osteoporosis Int 1995; 5: 239-246.

9. Chapuy MC, Arlot ME, Duboeuf F, Brun J, Crouzet B, Arnaud S, Delmas PD, Meunier PJ. Vitamin D3 and calcium to prevent hip fractures in the elderly women. $N$ Engl J Med 1992; 327: 1637-1642.

10. Dawson-Hughes B, Harris SS, Krall EA, Dallal GE. Effect of calcium and vitamin D supplementation on bone density in men and women 65 years of age or older. N Engl J Med 1997; 337: 670-677.

11. Lips P, Graafmans WC, Ooms ME, Bezemer PD, Bouter LM. Vitamin D supplementation and fracture incidence in elderly persons. A randomised, placebo-controlled clinical trial. Ann Intern Med 1996; 124: 400406.

12. Gillespie WJ, Henry DA, O'Connell DL, et al. Vitamin D and Vitamin D analogues in the prevention of fractures in involutional and post-menopausal osteoporosis. In Gillespie WJ, Madhok R, Swiontkowski M, Robinson CM, Murray GD, editors. Musculoskeletal Injuries Module of The Cochrane Database of Systematic Reviews. Issue 2. Oxford: The Cochrane Collaboration, 1997.

13. Falch JA, Kaastad TS, Bohler G, Espeland J, Sundsvold OJ. Secular increase and geographical differences in hip fracture incidence in Norway. Bone 1993; 14: 643-645. 
14. Lofthus CM, Osnes EK, Falch J, Kaastad TS, Kristiansen IS, Meyer HE, Stensvold I, Nordsletten L. Incidence of hip fractures in Oslo. $3^{\text {rd }}$ Baltic Bone \& Cartilage Conference, Ronneby, Sweden, August 1999. Acta Orthop Scand 1999; 70 (Suppl 287): 28.

15. Kvaavik E. En forundersøkelse til prosjektet "Forebyggelse av lårhalsbrudd”. Inntak av kalsium og vitamin D på sykehjem i Oslo. Cand. scient.oppgave, Ernæringsinstituttene, Universitetet i Oslo, 1997.

16. Statens ernæringsråd. Utviklingen i norsk kosthold, 1998.

17. Aas AM. Spørreskjema som metode for å avdekke vitamin D- og kalsium-inntak hos pasienter ved alders- og sykehjem i Oslo. Prosjektoppgave våren 1995. Nordiska högskolan för hushållsvetenskap, Linjen för näringsterapi, Institutt för klinisk näringslära, Annedalsklinikerna, Gøteborg, 1995.

18. Statens ernæringsråd. Norske næringsstoffanbefalinger, 1997.

19. Sjøen RJ. Vitamin D-status hos eldre på aldersinstitusjoner i Oslo. Hovedfagsoppgave. Institutt for ernæringsforskning og Avdeling for kostholdsforskning, Universitetet i Oslo, 1984.

20. Sem SW, Nes M, Engedal K, Pedersen JI, Trygg K. An attempt to identify and describe a group of noninstitutionalised elderly with the lowest nutrient score. Compr Gerontol A 1988; 2: 60-66.

21. Nes M, Sem SW, Pedersen JI, Trygg K. Dietary intake in a group of independent-living old people in Oslo. Ageing Clin Exp Res 1992; 4: 145-156.

22. Nes M, Frost Andersen L, Solvoll K, Sandstad B, Hustvedt BE, Løvø A, Drevon CA. Accuracy of a quantitative food frequency questionnaire applied in elderly Norwegian women. Eur J Clin Nutr 1992; 46: 809-821.

23. Nes M, Lund-Larsen K, Trygg K, Høivik HO, Pedersen JI. Nutrition and the elderly in Europe: low prevalence of obesity and biochemical deficiencies in the Norwegian subjects. Age Nutrition 1993; 4: $72-81$.

24. Cummings SR, Browner WS, Bauer D, Stone K, Ensrud K, Jamal S, Ettinger B. Endogenous hormones and the risk of hip and vertebral fractures among older women. N Engl J Med 1998; 339: 733-738.

25. Rosenstreich SJ, Rich C, Vollwiller W. Deposition in and release of vitamin $\mathrm{D}_{3}$ from body fat: evidence for a storage site in the rat. J Clin Invest 1971; 50: 679-687.

26. Aksnes L, Aarskog D. Vitamin D metabolites in serum from hypoparathyroid patients treated with vitamin $\mathrm{D}_{2}$ and 1-hydroxy vitamin $\mathrm{D}_{3}$. J Clin Endocrinol Metab 1980; 51: 823-829. 